\title{
SALIVARY GLAND PROTEINS OF THE HUMAN MALARIA VECTOR, Anopheles dirus B (DIPTERA: CULICIDAE)
}

\author{
Narissara JARIYAPAN(1), Wej CHOOCHOTE(1), Atchariya JITPAKDI(1), Thasaneeya HARNNOI(1), Padet SIRIYASATEIN(2), Mark C. WILKINSON(3), \\ Anuluck JUNKUM(1) \& Paul A. BATES(4)
}

\begin{abstract}
SUMMARY
Salivary gland proteins of the human malaria vector, Anopheles dirus B were determined and analyzed. The amount of salivary gland proteins in mosquitoes aged between 3 - 10 days was approximately $1.08 \pm 0.04 \mu \mathrm{g} / \mathrm{female}$ and $0.1 \pm 0.05 \mu \mathrm{g} / \mathrm{male}$. The salivary glands of both sexes displayed the same morphological organization as that of other anopheline mosquitoes. In females, apyrase accumulated in the distal regions, whereas alpha-glucosidase was found in the proximal region of the lateral lobes. This differential distribution of the analyzed enzymes reflects specialization of different regions for sugar and blood feeding. SDSPAGE analysis revealed that at least seven major proteins were found in the female salivary glands, of which each morphological region contained different major proteins. Similar electrophoretic protein profiles were detected comparing unfed and blood-fed mosquitoes, suggesting that there is no specific protein induced by blood. Two-dimensional polyacrylamide gel analysis showed the most abundant salivary gland protein, with a molecular mass of approximately 35 kilodaltons and an isoelectric point of approximately 4.0. These results provide basic information that would lead to further study on the role of salivary proteins of $A n$. dirus $\mathrm{B}$ in disease transmission and hematophagy.
\end{abstract}

KEYWORDS: Anopheles; Salivary gland; Malaria; Apyrase; Alpha-glucosidase.

\section{INTRODUCTION}

Salivary glands of mosquitoes play an important role in food ingestion and digestion as well as transmission of pathogens. The saliva produced by the arthropod salivary glands is the vehicle that carries pathogens and it may also enhance or facilitate infectivity during the blood meal ${ }^{43}$. Biochemically active protein molecules contained in the saliva counteract vertebrate haemostasis, allowing the arthropods to feed successfully ${ }^{37}$. In addition, the saliva contains immunogens that cause human IgE and lymphocyte-mediated hypersensitivities ${ }^{30}$. Analyses of salivary gland proteins of hematophagous mosquitoes have been reported in Aedes aegypti ${ }^{17,29,48}$, Anopheles stephensi ${ }^{45,53}$, An. gambiae $^{1,10}$, An. darlingi $i^{23,24}$, Culex pipiens ${ }^{3}$, Cx. quinquefasciatus ${ }^{25}$, Ae. togoi $^{18}$ and Armigeres subalbatus ${ }^{40}$. These previous analyses have mainly concentrated on the use of Sodium dodecyl sulphate polyacrylamide gel eletrophoresis (SDS-PAGE). Although twodimensional polyacrylamide gel elecrophoresis (2D-PAGE) is considered to be the best method available for resolving complex mixtures of proteins ${ }^{20,28}$, very little information is available on $2 \mathrm{D}$ PAGE analysis of mosquito salivary gland proteins.

An. dirus complexes comprise at least seven species ${ }^{44}$. Most of them are major vectors of malaria. Species A is widespread throughout
Thailand except in the south. Species B and C are found in sympatricity in southern Thailand. Species D is commonly found in the north-western side of Thailand, and in sympatricity with species A along the ThaiMyanmar border. It is also found exclusively in Myanmar and Bangladesh and the north-eastern states of India. Species E is exclusively found in western India and the Shimoga hills in Karnataka. Species F (An. nimophilus, Peyton and Ramalingam 1988) is found on the Thai-Malaysia border and is also reported from the monsoon forests of mountain areas in south-eastern, southern and western Thailand, and the Malaysian peninsular. An. takasagoensis is found exclusively in Taiwan ${ }^{44}$.

An. dirus B, which is one of the important malaria vectors, has been studied in many areas, for example, molecular studies of insect glutathione S-transferases ${ }^{26,27,32,33,34}$, genetic studies of Anopheles species complexes $^{2,13,49,50,51}$, and malaria transmission ${ }^{6,9,19,39,42}$. However, little is known about the salivary gland proteins of this mosquito species. In this study, its salivary gland proteins were determined and analyzed. We report, herewith, the differential distribution of salivary components within the glands of female mosquitoes, and our initial finding on the most abundant salivary gland protein of An. dirus B after 2D-PAGE analysis. The information obtained from this study would be an initial step for further identification of the most abundant salivary gland 
proteins that may have a role in blood feeding and/or malaria transmission.

\section{MATERIALS AND METHODS}

Mosquito: Anopheles dirus B mosquitoes that originated from the Armed Forces Research Institute of Medical Sciences (AFRIMS) laboratory, Bangkok, Thailand were used in this study. The mosquito colony was routinely maintained in an insectary at the Department of Parasitology, Faculty of Medicine, Chiang Mai University, Thailand for many years. The mosquitoes were reared and maintained in the insectary at $27 \pm 2{ }^{\circ} \mathrm{C}$ with $70 \pm 10 \%$ relative humidity, and a photoperiod of 12:12 (light/dark) hours. Mosquitoes aged between three and seven days after emergence were used. Adult mosquitoes were given continuous access to a $10 \%$ sucrose solution and fed on blood from immobilized mice when required.

Salivary gland dissection: Salivary glands of adult mosquitoes were dissected using fine entomological needles under a stereoscopic microscope at $4 \mathrm{X}$ magnification in phosphate-buffered saline [PBS; $10 \mathrm{mM} \mathrm{Na}_{2} \mathrm{SO}_{4}, 145 \mathrm{mM} \mathrm{NaCl}(\mathrm{pH} \mathrm{7.2)})$ and transferred to a microcentrifuge tube with a small volume of PBS. Dissection of various regions of the female salivary glands was also performed. The medial lobes were cut at the junction of the medial and lateral lobes. The distal-lateral and proximal-lateral lobes were cut at the intermediate region separating the two lobes. The gland parts were immediately removed to separate the tubes in order to avoid possible protein contamination between the different sections of the glands. The gland parts were placed in a small volume of PBS and stored at $-80{ }^{\circ} \mathrm{C}$ until use. Salivary glands of blood-fed mosquitoes were dissected within 20 min after taking a blood meal. These were either processed immediately for microscopy as described below or stored at $-80{ }^{\circ} \mathrm{C}$ for later biochemical analysis.

Light microscopy: The salivary glands of adult mosquitoes were dissected in PBS and allowed to settle onto slides without drying. Photographs of the glands were taken using a digital camera (Cannon, Tokyo, Japan) attached to a light microscope.

Protein quantification: The protein content of each salivary gland pair was determined using a Micro BCA Protein Assay Kit (Pierce, Rockford, IL) according to the manufacturer's instruction. The protein concentration was determined based on a bovine serum albumin (BSA) standard curve.

Apyrase enzymatic activity assay: Apyrase activity was determined as previously described by MARINOTTI et al..$^{21}$. One $\mu \mathrm{L}$ of salivary gland homogenate was incubated at $37{ }^{\circ} \mathrm{C}$ with $99 \mu \mathrm{L}$ of $50 \mathrm{mM}$ Tris- $\mathrm{HCl}$ buffer (pH 9.0), containing $100 \mathrm{mM} \mathrm{NaCl}, 5 \mathrm{mM}$ $\mathrm{CaCl}_{2}, 2 \mathrm{mM}$ Adenosine $\mathrm{S}^{\prime}$-Diphosphate (ADP) and $20 \mathrm{mM} \beta$ mercaptoethanol in a flat-bottom microtiter plate. After $15 \mathrm{~min}$, the reaction was interrupted by the addition of $2 \mu \mathrm{L}$ of reducing reagent (0.02\% 1-amino-2-napol-4-sulfonic acid, $0.12 \%$ sodium bisulfite, $0.12 \%$ sodium sulfite) and $25 \mu \mathrm{L}$ of $1.25 \mathrm{M} \mathrm{H}_{2} \mathrm{SO}_{4}$ containing $1.25 \%$ ammonium molybdate. The activity was determined colorimetrically in an ELISA reader at $630 \mathrm{~nm}$. The standard curve for the inorganic phosphorous produced was determined according to FISKE \& SUBARROW ${ }^{8}$.
Enzymatic assay for alpha-glucosidase activity detection: Alphaglucosidase activity was determined by the glucose oxidase-peroxidase method $^{7}$. The reactions were carried out in flat-bottom microtiter plates. Ten microliters of salivary gland homogenate were incubated for 30 min at $37{ }^{\circ} \mathrm{C}$ with $10 \mu \mathrm{L}$ of $100 \mathrm{mM}$ phosphate buffer $(\mathrm{pH} \mathrm{7.0)}$, containing $0.1 \mathrm{M}$ sucrose. After that, $150 \mu \mathrm{L}$ of $0.5 \mathrm{M}$ Tris- $\mathrm{HCl}, \mathrm{pH}$ 7.0, containing $25 \mathrm{U}$ of glucose oxidase, $10 \mathrm{mg}$ O-dianisidine, $0.0125 \%$ Triton X-100 dissolved in $95 \%$ ethanol and $2.5 \mathrm{U}$ of peroxidase were added, and the reaction was incubated at $37{ }^{\circ} \mathrm{C}$ for one h. The activity was determined colorimetrically in an ELISA reader at $405 \mathrm{~nm}$. A glucose concentration standard curve was used to determine the amount of glucose produced in the reaction.

Sodium dodecyl sulphate polyacrylamide gel electrophoresis (SDS-PAGE): SDS-PAGE was carried out according to standard techniques ${ }^{15}$. Salivary gland samples were thawed on ice and mixed in 1:2 1X SDS gel loading buffer [50 mM Tris- $\mathrm{HCl}$ (pH 6.8), $100 \mathrm{mM}$ DTT, $2 \%$ SDS, $0.1 \%$ Bromophenol blue, $10 \%$ glycerol]. Then, the samples were heated for five min in a boiling water bath and loaded on $12 \%$ SDS polyacrylamide gels. Molecular weight markers (Bio-rad, USA) were applied in each gel.

Two-dimensional gel electrophoresis (2D-PAGE): Twodimensional gel electrophoresis was performed using the 2D system (Amersham Pharmacia, Sweden). Five pairs of female salivary glands were solubilized in a $125 \mu \mathrm{L}$ sample solubilization solution ( $8 \mathrm{M}$ urea, 50 mM DTT, 4\% CHAPS, 0.2\% 3/10 Bio-lyte Ampholyte, 0.0002\% Bromophenol Blue) and then loaded on an IPG strip (isoelectric point (pI) $3-10.7 \mathrm{~cm}$, Amersham Pharmacia, Sweden) to perform the first dimension isoelectric focusing (IEF) separation. The strip was incubated in equilibration buffer [6 M urea, 2\% SDS, $0.05 \mathrm{M}$ Tris (pH 8.8), 20\% glycerol] for $15 \mathrm{~min}$. SDS-PAGE slab gels (12\%) were used to separate proteins in the second dimension.

Coomassie Brilliant Blue (CBB) staining: Following the electrophoresis, gels were CBB-stained. First, the gels were fixed in $50 \%$ methanol and $10 \%$ acetic acid for $30 \mathrm{~min}$, then stained with $1 \%$ CBB in $10 \%$ methanol and 5\% acetic acid for two h, and finally destained in $10 \%$ methanol and 5\% acetic acid until dark protein bands or spots were visible. Digital images of both SDS-PAGE and 2D CBBstained gels were captured by scanning at 300 dpi using a color scanner.

\section{RESULTS}

The salivary glands of male and female An. dirus B mosquitoes are morphologically different. Those of adult females are paired organs lying in the thorax on either side of the esophagus. They have a single medial and two lateral lobes. The lateral lobe of each female salivary gland is composed of two secretory regions, proximal and distal, while the medial lobe has only one region (Fig. 1A). The salivary glands of males consist of a single small lobe (Fig. 1B).

The protein contents of whole salivary glands were quantified. The amount of salivary gland proteins in the mosquitoes aged between 3 10 days was approximately $1.08 \pm 0.04 \mu \mathrm{g} /$ female $(\mathrm{n}=30)$ and $0.1 \pm$ $0.05 \mu \mathrm{g} /$ male $(\mathrm{n}=30)$.

The biochemical analyses of the salivary glands of female An. dirus 


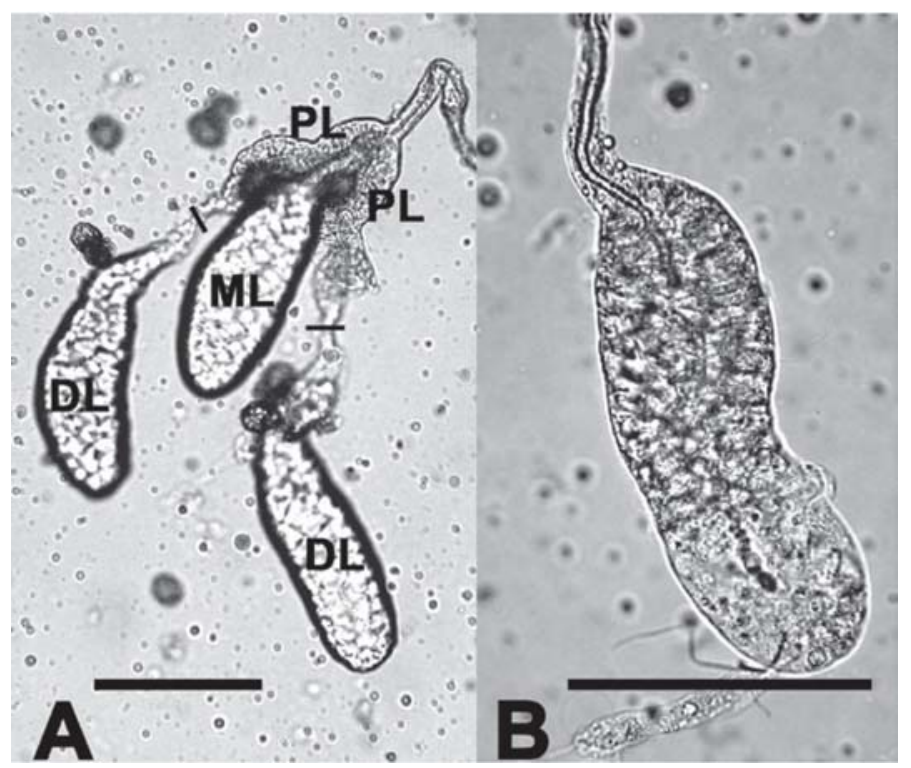

Fig. 1 - Representative adult salivary glands of the mosquito, Anopheles dirus B. (A) A female salivary gland. (B) A male salivary gland. PL: proximal region of the lateral lobe; DL: distal region of the lateral lobe; ML: median lobe. Bar represents $500 \mu \mathrm{m}$.

B revealed the presence of apyrase and alpha-glucosidase activities (Table 1). Apyrase activity was detected by the production of inorganic phosphorous following ADP hydrolysis. The activity determined at $\mathrm{pH}$ 9.0 (optimum pH), was $6.5 \pm 1.5 \mathrm{nmol}$ of inorganic phosphorous/minute/ salivary gland pair $(\mathrm{X} \pm$ standard deviation, $\mathrm{n}=10$ samples, each sample containing three salivary gland pairs). The activity of alpha-glucosidase detected by the production of glucose from sucrose hydrolysis at $\mathrm{pH} 7.0$ (optimum $\mathrm{pH}$ ), was $0.08 \pm 0.01$ of glucose/ minute/ salivary gland pairs ( $\mathrm{X} \pm$ standard deviation, $\mathrm{n}=30$ mosquitoes). The distribution of these two enzymes within the salivary glands of female mosquitoes was determined (Table 1). The apyrase activity was mostly concentrated in the distal region of the lateral lobes. Most of the alpha-glucosidase activity was present in the proximal region of the lateral lobes.

Total proteins in whole male and female salivary glands of $A n$. dirus $\mathrm{B}$, as well as the various micro-dissected morphological regions of female salivary glands, were examined in CBB stained SDSpolyacrylamide gels (Fig. 2A). At least seven major and several minor protein bands were detected in the female salivary glands (Fig. 2A, lane F), some of which were labeled (P1 through P7). The molecular masses of these major protein bands were estimated at $63,44,43,35$, 33,30 and 18 kilodaltons $(\mathrm{kDa})$, consecutively. The male gland protein profile differed from the female one and the protein content was lower

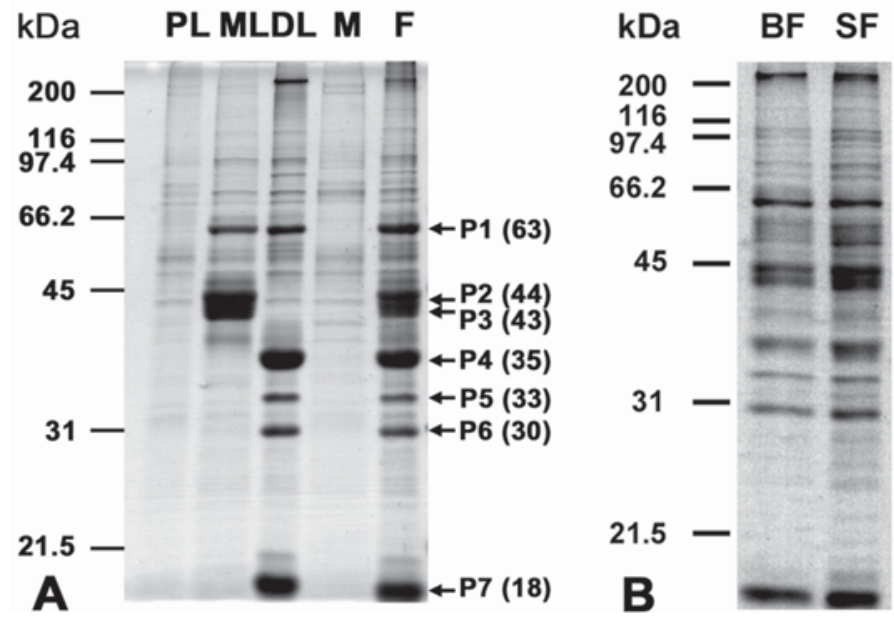

Fig. 2 - (A) Female and male salivary gland proteins of An. dirus B mosquitoes. Salivary proteins were separated on $12 \%$ SDS-polyacrylamide gels and stained with Coomassie Blue. Lane PL, ten proximal-lateral lobes; lane ML, ten median lobes; lane DL, ten distal-lateral lobes; lane M, fifty whole male salivary glands; lane F, ten whole female salivary glands. Molecular mass markers are indicated on the left in $\mathrm{kDa}$. Labels on the right indicate protein bands found specifically in the female glands (P1 - P7) and their estimated molecular mass (in blankets). (B) Comparison of female salivary gland protein profiles between blood-fed and sugar-fed An. dirus B. Lane BF, ten whole glands of blood-fed mosquitoes; lane SF, ten whole glands of sugar-fed mosquitoes. Molecular mass markers are indicated on the left in kDa.

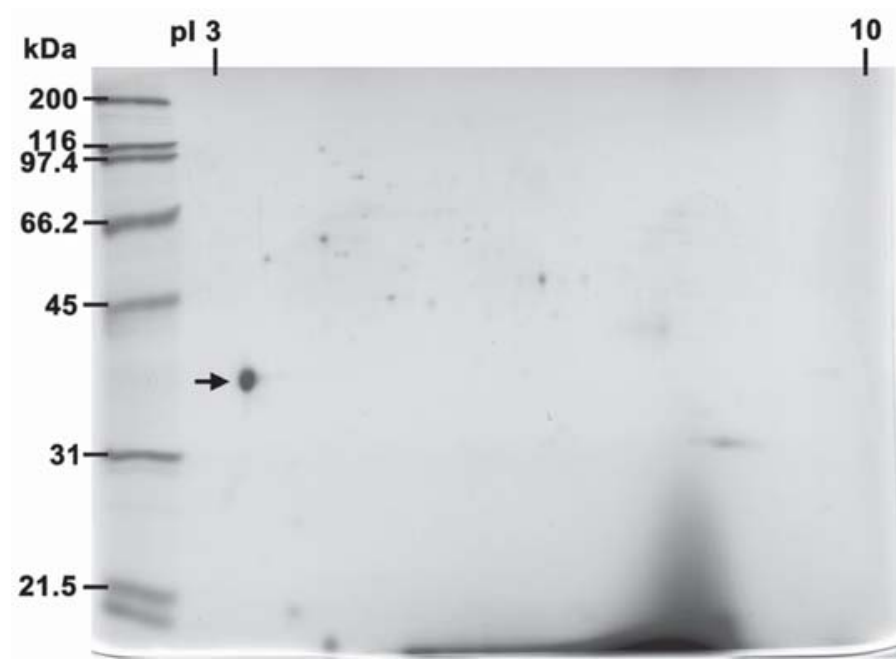

Fig. 3 - Coomassie Blue-stained 2D gel of proteins from three female salivary glands of $A n$. dirus $\mathrm{B}$. Arrow indicates a $35 \mathrm{kDa}$ spot, the most abundant protein expressed in the salivary glands. Molecular mass markers are indicated on the left in $\mathrm{kDa}$. Isoelectric points (pI) are indicated at the top.

Table 1

Distribution of apyrase and alpha-glucosidase within adult female An. dirus B salivary glands

\begin{tabular}{lccc}
\hline & Distal region of lateral lobe & Proximal region of lateral lobe & Medial lobe \\
\hline Apyrase $^{a}$ & $66 \%$ & $11 \%$ & $23 \%$ \\
Alpha-glucosidase $^{b}$ & $15 \%$ & $78 \%$ & $7 \%$
\end{tabular}

Apyrase activity was determined by inorganic phosphate production from ADP hydrolysis as described by MARINOTTI et al. ${ }^{21}(\mathrm{n}=20)^{a}$; alpha-glucosidase activity was determined by the release of glucose from sucrose by the glucose oxidase-peroxidase $\operatorname{method}^{7}(\mathrm{n}=20)^{b}$. The total activity in the glands was set as $100 \%$. 
(lane M, fifty male glands, compared with lane F, five female glands). The different morphological regions of the female salivary glands also displayed distinct protein electrophoretic profiles. The salivary gland protein bands, P1, P4, P5, P6 and P7, appeared predominantly in the distal region of the lateral lobe (Fig. 2A, lane DL), while the female specific protein bands, $\mathrm{P} 1, \mathrm{P} 2$ and $\mathrm{P} 3$, were predominant in the medial lobe (Fig. 2A, lane ML). The protein profile of the proximal region of the lateral lobe (Fig. 2A, lane PL) appeared similar to the profile of the male salivary glands (Fig. 2A, lane M).

Figure $2 \mathrm{~B}$ shows the salivary gland electrophoretic profiles of the blood-fed and sugar-fed mosquitoes. The protein profiles are basically similar, although there are minor differences in both after several repeats.

Separation of salivary gland proteins by 2D-PAGE yielded a protein profile with numerous individual spots, and a wide dynamic concentration range (Fig. 3). The most abundant salivary gland protein found in CBB stained 2D gels had a molecular mass of approximately $35 \mathrm{kDa}$, with a pI of approximately 4.0.

\section{DISCUSSION}

The morphology of female and male An. dirus B salivary glands is different. While the female glands are organized in two identical lateral lobes and a medial lobe, the salivary glands of males consist of a single small lobe. The female gland is similar to the salivary glands of Aedes, Culex and Anopheles species ${ }^{17,23,29,53}$. Previous studies reported that the salivary glands of male Aedes and Culex mosquitoes are composed of three identical lobes, all of them formed by cells morphologically similar to that of the female proximal portion of the lateral lobes ${ }^{43}$. However, the male salivary glands of An. dirus B follow the same morphological pattern as described for An. darlingi ${ }^{23}$.

Determination of the An. dirus B salivary gland extracts revealed that the male glands contained 10 times less protein than the female ones. These values are consistent with the morphological differences observed between the salivary glands of males and females. These morphological and protein content differences have been observed in other mosquito species and were related with the different feeding habits of males and females ${ }^{18,21,24,25}$. Females feed on both sugar and blood, whereas males feed on sugar only ${ }^{43}$.

The accumulation of specific proteins in the different salivary gland regions has been described for various mosquitoes ${ }^{31,35}$. Two enzymes, the apyrase and alpha-glucosidase, previously characterized in the salivary glands of Ae. aegypti ${ }^{22}$, Ae. albopictus ${ }^{21}, A n$. darlingi $i^{23}$ and $C x$. quinquefasciatus ${ }^{25}$, demonstrated accumulation preferentially in the distal region and proximal region of the lateral lobes, respectively. The salivary apyrase and alpha-glucosidase of An. dirus B females were found to have the same distribution pattern. The distal region of the lateral lobes is necessary for mosquito blood feeding. The apyrase, synthesized and accumulated in the female-specific region of the gland, has been related to inhibition of the platelet aggregation, which facilitates blood ingestion by the mosquitoes ${ }^{21,38}$. This enzyme is secreted by the salivary glands only during blood feeding.

Previous work on Ae. aegypti and Ae. albopictus indicates that the proximal regions of the lateral lobes of the mosquitoes' salivary glands synthesize and accumulate molecules that help in sugar solubilization, ingestion and digestion ${ }^{5,21}$. The Mal-I gene expressed exclusively in the cells of the proximal region of the Ae. aegypti salivary glands, encodes an alpha-glucosidase that is secreted during mosquito sugar feeding. This enzyme hydrolyzes sucrose, the major natural sugar source ${ }^{16,22}$.

In this study, the overall profiles of female and male salivary gland proteins of An. dirus B were analyzed. The protein profiles present in male and female glands are distinctly different. At least seven major proteins visualized after SDS-PAGE are female specific. One possibility is that the polypeptides not found in males are synthesized by femalespecific cells and are involved in blood feeding. The predominant protein bands found in the distal region of the lateral lobes and the medial lobes of female glands were not present in the glands from non-blood sucking males that lack these regions. Specific proteins produced in different parts of the salivary glands of female An. dirus B are consistent with previous studies on salivary gland profiles of $A n$. stephensi $^{45}$, Ae. togoi $^{18}$ and Ar. subalbatus ${ }^{40}$.

The protein profile of the salivary glands of sugar-fed female $A n$. dirus B mosquitoes was compared with that of blood-fed ones. The major protein bands in the glands of both sugar-fed and blood-fed mosquitoes showed similar profiles. These results correlate with the analysis of the salivary gland proteins of sugar-fed and blood-fed $A n$. darlingi mosquitoes ${ }^{24}$. In other Anopheles species, although the total salivary gland protein content of blood-fed mosquitoes (An. stephensi, An. albimanus, An. gambiae, An. freeborni, and An. darlingi) is at least $10 \%$ less than that of sugar-fed controls, small differences in the amount of proteins are difficult to visualize in Coomassie Blue stained gels and/or silver stained gels ${ }^{12}$. ORR et al..$^{29}$ observed a change in the salivary gland cells 24 hours after Ae. aegypti females had taken blood meals; the nucleoli of the median and lateral acini became greatly enlarged and there was a concomitant increase in RNA around the nuclei. They concluded that blood feeding may deplete the female Ae. aegypti salivary glands, and this depletion would lead to resynthesis of secretory products within 24 hours. Furthermore, SOLIMAN et al. ${ }^{41}$ reported that after $C x$. pipiens had blood-fed, the total saliva was depleted by $64 \%$ within 24 hours, but the protein level returned to the unfed value within the next 24 - 48 hours. In Ar. subalbatus, however, salivary gland protein profiles between unfed and blood-fed mosquitoes were significantly different. Immediately after blood feeding, the proteins, 65 and $21 \mathrm{kDa}$, which abundantly expressed in the distal regions of the lateral lobes, were barely detectable. However, they started to appear gradually six hours later and returned to the unfed level within 48 hours $^{40}$. Results from these studies suggest that mosquitoes in a different genus may have different biochemically active molecules involving blood feeding and/or the blood digestion process.

Usually, proteomic study of the saliva and salivary glands of arthropods use SDS-PAGE to separate proteins and N-terminal sequence analysis for identification in, for example, Ae. aegypti ${ }^{48}$, An. stephensi ${ }^{47}$, An. gambiae $^{10}, A n$. darlingi ${ }^{4}, C x$. quinquefasciatus ${ }^{36}$, and Ixodes scapularis $^{46}$. Recent improvements in 2D-PAGE, mass spectrometry, and bioinformatics provide additional tools to characterize small amounts of protein. These methods were employed to characterize salivary proteins from Amblyomma americanum ${ }^{20}$, A. maculatum $^{20}$, and 
JARIYAPAN, N.; CHOOCHOTE, W.; JITPAKDI, A.; HARNNOI, T.; SIRIYASATEIN, P.; WILKINSON, M.C.; JUNKUM, A. \& BATES, P.A. - Salivary gland proteins of the human malaria vector, Anopheles dirus B (Diptera: Culicidae). Rev. Inst. Med. trop. S. Paulo, 49(1): 5-10, 2007.

Glossina morsitans morsitans ${ }^{14}$. In this study, 2D-PAGE was also used to separate the salivary gland proteins of An. dirus $\mathrm{B}$. The results showed that the major protein bands present on SDS-polyacrylamide gels were separated into numerous individual spots with different concentrations and $\mathrm{pI}$. In addition, the most abundant protein expressed was detectable. It had a molecular mass of approximately $35 \mathrm{kDa}$ and was very acidic, with a $\mathrm{pI}$ of approximately 4.0. Further analysis by matrix-assisted, laser desorption ionization mass spectrometry (MALDI-MS) and tandem mass spectrometry methods would provide peptide mass maps and sequences that are often sufficient in identifying proteins ${ }^{11}$. The sequence information and peptide mass map can be used to query against an NCBI non-redundant database to confirm the identity of the protein. In our laboratory, identification and characterization of this major protein and analysis of $A n$. dirus B salivary gland transcriptome are currently in progress. Results in this study provide information that is an initial step towards further investigations of molecular, biochemical and immunological aspects in the role of salivary proteins of An. dirus B in disease transmission and blood feeding.

\section{RESUMO}

\section{Proteínas das glândulas salivares do Anopheles dirus B (Diptera: Culicidae), vetor da malária humana}

Proteínas das glândulas salivares do Anopheles dirus B (Diptera: Culicidae), vetor da malária humana foram determinadas e analisadas. A quantidade de proteínas das glândulas salivares em mosquitos com três a 10 dias de idade foi de aproximadamente 1,08 $\pm 0,04 \mu \mathrm{g}$ / fêmea e de $0,1 \pm 0,05 \mu \mathrm{g} /$ macho. As glândulas salivares de ambos os sexos mostraram organização morfológica semelhante à de outros mosquitos anofelinos. Em fêmeas, apirase acumula-se nas regiões distais, enquanto alfa-glucosidase foi encontrada na região proximal dos lóbulos laterais. Esta distribuição diferencial das enzimas analisadas reflete a especialização de diferentes regiões para alimentação de açucares e sangue. Análise SDS-PAGE revelou que pelo menos sete proteínas foram encontradas nas glândulas salivares de fêmeas, das quais cada região morfológica continha diferentes proteínas principais. Perfis eletroforéticos de proteínas semelhantes foram detectados comparandose mosquitos não alimentados e alimentados por sangue, sugerindo que não existe proteína específica induzida pelo mesmo. Análise por gel poliacrilamida bi-dimensional mostrou a mais abundante proteína de glândulas salivares com aproximadamente 35 kilodaltons de massa molecular e ponto isoelétrico de aproximadamente 4,0. Estes resultados dão informações básicas que levariam a estudos adicionais sobre o papel das proteínas salivares do An. dirus B na transmissão da doença e hematofagia.

\section{ACKNOWLEDGEMENTS}

The authors sincerely thank the Faculty of Medicine Endowment Fund, Chiang Mai university for financially supporting this research project.

\section{REFERENCES}

1. ARCA, B.; LOMBARDO, F.; De LARA CAPURRO, M. et al. - Trapping cDNAs encoding secreted proteins from the salivary glands of the malaria vector Anopheles gambiae. Proc. nat. Acad. Sci. (Wash.), 96: 1516-1521, 1999.
2. BAIMAI, V.; GREEN, C.A.; ANDRE, R.G.; HARRISON, B.A. \& PEYTON, E.L. Cytogenetic studies of some species complexes of Anopheles in Thailand and Southeast Asia. Southeast Asian J. trop. Med. publ. Hlth., 15: 536-546, 1984.

3. BARROW, P.M.; McCIVER, S.B. \& WRIGHT, K.A. - Salivary glands of female Culex pipiens: morphological changes associated with maturation and blood feeding. Canad. J. Zool., 107: 1153-1160, 1975.

4. CALVO, E.; ANDERSEN, J.; FRANCISCHETTI, I.M. et al. - The transcriptome of adult female Anopheles darlingi salivary glands. Insect Molec. Biol., 13: 73-88, 2004.

5. CLEMENTS, A.N. - The biology of mosquitoes. v. 1: Development, nutrition and reproduction. London, Chapman \& Hall, 1992. v. 1, p. 251-262.

6. COLEMAN, R.E.; POLSA, N.; EIKARAT, N.; KOLLARS Jr., T.M. \& SATTABONGKOT, J. - Prevention of sporogony of Plasmodium vivax in Anopheles dirus mosquitoes by transmission-blocking antimalarials. Amer. J. trop. Med. Hyg., 65: 214-218, 2001.

7. DAHLQVIST, A. - Assay of intestinal disaccharidases. Analyt. Biochem., 22: 99, 1968.

8. FISKE, C.H. \& SUBARROW, Y. - The colorimetric determination of phosphorus. J. biol. Chem., 6: 375-497, 1925.

9. FRANCES, S.P.; KLEIN, T.A.; WIRTZ, R.A. et al. - Plasmodium falciparum and $P$. vivax circumsporozoite proteins in Anopheles (Diptera: Culicidae) collected in eastern Thailand. J. med. Entomol., 33: 990-991, 1996.

10. FRANCISCHETTI, I.M.B.; VALENZUELA, J.G.; PHAM, V.M.; GARFIELD, M.K. \& RIBEIRO, J.M.C. - Toward a catalog for the transcripts and proteins (sialome) from the salivary gland of the malaria vector Anopheles gambiae. J. exp. Biol., 205: 24292451, 2002.

11. GEVAERT, K. \& VANDEKERCKHOVE, J. - Protein identification methods in proteomics. Electrophoresis, 21: 1145-1154, 2000.

12. GOLENDA, C.F.; KLEIN, T.; COLEMAN, R. et al. - Depletion of total salivary gland protein in blood-fed Anopheles mosquitoes. J. med. Entomol., 32: 300-305, 1995.

13. GREEN, C.A.; MUNSTERMANN, L.E.; TAN, S.G.; PANYIM, S. \& BAIMAI, V. Population genetic evidence for species A, B, C, and D of the Anopheles dirus complex in Thailand and enzyme electromorphs for their identification. Med. vet. Entomol., 6: $29-36,1992$.

14. HADDOW, J.D; POULIS, B; HAINES, L.R et al. - Identification of major soluble salivary gland proteins in teneral Glossina morsitans morsitans. Insect Biochem. Molec. Biol., 32: 1045-1053, 2002.

15. HAMES, B.D. - One-dimensional polyacrylamide gel electrophoresis. In: HAMES, B.D \& RICKWOOD, D., ed. Gel electrophoresis of proteins. Oxford, IRL Press, 1990. p. $1-147$.

16. JAMES, A.A.; BLACKMER, K. \& RACIOPPI, J.V. - A salivary gland-specific, maltaselike gene of the vector mosquito, Aedes aegypti. Gene, 75: 73-83, 1989.

17. JANZEN, H.G. \& WRIGHT, K.A. - The salivary glands of Aedes aegypti (L.): an electron microscope study. Canad. J. Zool., 49: 1343-1345, 1971.

18. JARIYAPAN, N. \& HARNNOI, T. - Preliminary study of salivary gland proteins of the mosquito Aedes togoi (Theobald). Chiang Mai Med. Bull., 41: 21-28, 2002.

19. KLEIN, T.A.; HARRISON, B.A.; DIXON, S.V. \& BURGE, J.R. - Comparative susceptibility of Southeast Asian Anopheles mosquitoes to the simian malaria parasite Plasmodium cynomolgi. J. Amer. Mosq. Contr. Ass., 7: 481-487, 1991.

20. MADDEN, R.D.; SAUER, J.R. \& DILLWITH, J.W. - A proteomics approach to characterizing tick salivary secretions. Exp. Appl. Acarol., 28: 77-87, 2002. 
JARIYAPAN, N.; CHOOCHOTE, W.; JITPAKDI, A.; HARNNOI, T.; SIRIYASATEIN, P.; WILKINSON, M.C.; JUNKUM, A. \& BATES, P.A. - Salivary gland proteins of the human malaria vector, Anopheles dirus B (Diptera: Culicidae). Rev. Inst. Med. trop. S. Paulo, 49(1): 5-10, 2007.

21. MARINOTTI, O.; BRITO, M. \& MOREIRA, C.K. - Apyrase and alpha-glucosidase in the salivary glands of Aedes albopictus. Comp. Biochem. Physiol., 113B: 675-679, 1996

22. MARINOTTI, O. \& JAMES, A.A. - An $\alpha$-glucosidase in the salivary glands of the vector mosquito, Aedes aegypti. Insect Biochem., 20: 619-623, 1990.

23. MOREIRA-FERRO, C.K.; MARINOTTI, O. \& BIJORSKY, A.T. - Morphological and biochemical analyses of the salivary glands of the malaria vector, Anopheles darlingi. Tissue Cell, 31: 264-273, 1999.

24. MOREIRA, C.K.; MARRELLI, M.T.; LIMA, S.P. \& MARINOTTI, O. - Analysis of salivary gland proteins of the mosquito Anopheles darlingi (Diptera: Culicidae). J. med. Entomol., 38: 763-767, 2001

25. NASCIMENTO, E.P.; MALAFRONTE, R.S. \& MARINOTTI, O. - Salivary gland proteins of the mosquito Culex quinquefasciatus. Arch. Insect Biochem. Physiol., 43: $9-15,2000$

26. OAKLEY, A.J.; KETTERMAN, A. \& WILCE, M.C. - Structural biology and its applications to the health sciences. Croat. med. J., 42: 375-378, 2001.

27. OAKLEY, A.J.; HARNNOI, T.; UDOMSINPRASERT, R. et al. - The crystal structures of glutathione S-transferases isozymes 1-3 and 1-4 from Anopheles dirus species B. Protein Sci., 10: 2176-2185, 2001.

28. O'FARRELL, P.H. - High resolution two-dimensional electrophoresis of proteins. J. biol. Chem., 250: 4007-4021, 1975 .

29. ORR, C.W.M.; HUDSON, A. \& WEST, A.S. - The salivary glands of Aedes aegypti: histological-histochemical studies. Canad. J. Zool., 39: 265-272, 1961.

30. PENG, Z. \& SIMONS, F.E. - Mosquito allergy: immune mechanisms and recombinant salivary allergens. Int. Arch. Allergy Immunol., 133: 198-209, 2004.

31. POEHLING, H.M. - Distribution of specific proteins in the salivary gland lobes of Culicidae and their relation to age and blood sucking. J. Insect Physiol., 25: 3-8, 1979.

32. PRAPANTHADARA, L.; KOOTTATHEP, S.; PROMTET, N.; HEMINGWAY, J. \& KETTERMAN, A.J. - Purification and characterization of a major glutathione Stransferase from the mosquito Anopheles dirus species B. Insect Biochem. Molec. Biol., 26: 277-285, 1996.

33. PRAPANTHADARA, L; PROMTET, N.; KOOTTATHEP, S.; SOMBOON, P. \& KETTERMAN, A.J. - Isoenzymes of glutathione S-transferase from the mosquito Anopheles dirus species B: the purification, partial characterization and interaction with various insecticides. Insect Biochem. Molec. Biol., 30: 395-403, 2000.

34. PRAPANTHADARA, L.; RANSON, H.; SOMBOON, P. \& HEMINGWAY, J. - Cloning, expression and characterization of an insect class I glutathione S-transferase from Anopheles dirus species B. Insect Biochem. Molec. Biol., 28: 321-329, 1998.

35. RACIOPPI, J.V. \& SPIELMAN, A. - Secretory proteins from the salivary glands of adult Aedes aegypti mosquitoes. Insect Biochem., 17: 503-511, 1987.

36. RIBEIRO, J.M.; CHARLAB, R.; PHAM, V.M.; GARFIELD, M. \& VALENZUELA, J.G. - An insight into the salivary transcriptome and proteome of the adult female mosquito Culex pipiens quinquefasciatus. Insect Biochem. Molec. Biol., 34: 543-563, 2004.

37. RIBEIRO, J.M. \& FRANCISCHETTI, I.M. - Role of arthropod saliva in blood feeding: sialome and post-sialome perspectives. Ann. Rev. Entomol., 48: 73-88, 2003.
38. ROSSIGNOL, P.A.; RIBEIRO, J.M. \& SPIELMAN, A. - Increase intradermal probing time in sporozoite-infected mosquitoes. Amer. J. trop. Med. Hyg., 33: 17-20, 1984.

39. SINGHASIVANON, P.; THIMASARN, K.; YIMSAMRAN, S. et al. - Malaria in tree crop plantations in south-eastern and western provinces of Thailand. Southeast Asian J. trop. Med. publ. Hlth, 30: 399-404, 1999

40. SIRIYASATIEN, P.; TANGTHONGCHAIWIRIYA, K.; JARIYAPAN, N. et al. - Analysis of salivary gland proteins of the mosquito Armigeres subalbatus. Southeast Asian J. trop. Med. publ. Hlth, 36: 64-67, 2005.

41. SOLIMAN, M.A.; ABDEL-HAMID, M.E.; MANSOUR, M.M. et al. - Total salivary gland proteins of female Culex pipiens and Aedes caspius (Diptera: Culicidae) and their fractionation during adult development and after blood sucking. J. Egypt. Soc. Parasit., 29: 619-634, 1999.

42. SOMBOON, P. \& MORAKOTE, N. - Infectivity of gametocytes of Plasmodium falciparum and Plasmodium vivax after storage in vitro. Ann. trop. Med. Parasit., 84: 89-91, 1990 .

43. STARK, K.R. \& JAMES, A.A. - The salivary glands of disease vectors. In: BEATY, B.J. \& MARQUARDT, W.C., ed. The Biology of disease vectors. Colorado, University Press of Colorado, 1996. p. 333-348.

44. SUBBARAO, S.K. - Anopheline species complexes in South-East Asia. New Delhi, WHO Regional Office for South-East Asia, 1998. p. 25-33. (SEARO No. 18).

45. SUWAN, N.; WILKINSON, M.C.; CRAMPTON, J.M. \& BATES, P.A. - Expression of D7 and D7-related proteins in the salivary glands of the human mosquito Anopheles stephensi. Insect Molec. Biol., 11: 223-232, 2002.

46. VALENZUELA, J.G.; FRANCISCHETTI, I.M.; PHAM, V.M. et al. - Exploring the sialome of the tick Ixodes scapularis. J. exp. Biol., 205: 2843-2864, 2002.

47. VALENZUELA, J.G.; FRANCISCHETTI, I.M.; PHAM, V.M.; GARFIELD, M.K. \& RIBEIRO, J.M. - Exploring the salivary gland transcriptome and proteome of the Anopheles stephensi mosquito. Insect Biochem. Molec. Biol., 33: 717-732, 2003.

48. VALENZUELA, J.G.; PHAM, V.M.; GARFIELD, M.K.; FRANCISCHETTI, I.M. \& RIBEIRO, J.M. - Toward a description of the sialome of the adult female mosquito Aedes aegypti. Insect Biochem. Molec. Biol., 32: 1101-1122, 2002.

49. WALTON, C.; CHANG, M.S.; HANDLEY, J.M. et al. - The isolation and characterization of microsatellites from Anopheles dirus mosquitoes. Molec. Ecol., 9: 1665-1667, 2000 .

50. WALTON, C.; HANDLEY, J.M.; COLLINS, F.H. et al. - Genetic population structure and introgression in Anopheles dirus mosquitoes in Southeast Asia. Molec. Ecol., 10: $569-580,2001$

51. WALTON, C.; HANDLEY, J.M.; KUVANGKADILOK, C. et al. - Identification of five species of the Anopheles dirus complex from Thailand, using allele-specific polymerase chain reaction. Med. vet. Entomol., 13: 24-32, 1999.

52. WALTON, C.; HANDLEY, J.M.; TUN-LIN, W. et al. - Population structure and population history of Anopheles dirus mosquitoes in Southeast Asia. Molec. Biol. Evol., 17: 962-974, 2000.

53. WRIGHT, K.A. - The anatomy of salivary glands of Anopheles stephensi Liston. Canad. J. Zool., 47: 579-587, 1969.

Received: 23 September 2005

Accepted: 14 July 2006 